\title{
Climate Change Effects on Policing in Delta State, Nigeria
}

\author{
Sunday I. Efe, Alex Eyefia \\ Department of Geography and Regional Planning, Delta State University, Abraka, Nigeria \\ Email: efesundayighovie@gmail.com
}

Received 16 April 2015; accepted 19 May 2015; published 22 May 2015

Copyright (C) 2015 by authors and Scientific Research Publishing Inc. This work is licensed under the Creative Commons Attribution International License (CC BY). http://creativecommons.org/licenses/by/4.0/

\section{(c) (i) Open Access}

\begin{abstract}
The study assesses the effects of climate change on police operation in Delta state. To achieve this climate, data were extracted from the archives of the Nigerian Meteorological Agency and the Met Station of the Department of Geography Delta State University Abraka, and police operation data were collected from the archive of the police diary at the state police headquarter. The results showed an evidence of climate change in delta state with a rise of $3^{\circ} \mathrm{C}$ in temperature, and decadal rainfall increase of $120 \mathrm{~mm} ; 56 \mathrm{~mm}$ and $121 \mathrm{~mm}$ in three epochs (1975-1984, 1985-1994 and 1995-2014). The first and last decades are wetter than the second epoch. There is a general increase in annual Police and vigilant operations from 1975 to 2014 and their operations are significantly dependent on increase in rainfall and rise in temperature. Thus increase in rainfall and rise in temperature bring corresponding reduction in police and local vigilante operations in the state. It therefore recommended that federal and state government should provide rain coat, safety boot, umbrella, good vehicles to police on duty; and police and vigilante should embark on regular patrol be it raining or sunny day. This is because crimes (breaking and entry, armed robbery etc.) increase when it is raining heavily.
\end{abstract}

\section{Keywords}

Rainfall, Temperature, Highway Patrol, Street Patrol, Vigilante Patrol

\section{Introduction}

Climate change threat and vulnerability did not only transcend one continent to another, but from one country to another, and even amongst communities. Despite its disproportionate impact over the world, most studies on climate change and security have originated from developed countries. Upon this regard, discussing security impacts of climate change in Nigeria is crucial, based partly on two factors. Firstly, the dynamics of its internal security 
and stability of Nigeria has regional and continental ramifications because Nigerian constitutes about $20 \%$ of the population of sub-Saharan Africa. Secondly, the country is bedevilled with high poverty and unemployment rate, wide income and gender inequality, prevalence of diseases (HIV/AIDS and malaria), endemic corruption, and the existence of separatist and militant groups, negative which are human development indices. This prevailing situation foregrounds much of the internal security complex and dynamics that climate change is set to trigger or exacerbate in Nigeria. Climate change has become one of the most challenging global issues facing humanity and certain urban characteristics that have relevance for understanding risks from climate and weather hazards [1]. This issue is particularly salient today given the growing consensus among criminologists and law enforcement officials on the benefits of highly targeted crime prevention strategies that focus police resources on "hot spots" and "hot times" rather than relying on more broad-based interventions. [2] emphasized the importance of specific times and locations that bring together likely offenders, suitable targets and the absence of capable guardians, resulting in extremely high crime rates. Given its strong impact on current period crime, weather conditions may be a plausible instrument for identifying the impact of lagged crime on current police activity.

The effect that changing weather conditions have on criminal and aggressive behaviour has long been a subject of interest both to scientists and the lay public. For instance weather hazards can triggers negative emotional responses' [3]. Weather influence on suicide rates has been documented see [4] [5]. While those on weather and crime are widely scattered in different journals and disciplines and have never before been collected into a comprehensive literature review [6] [7]. However, the relationship between weather and crime and criminal behaviour was not studied seriously, until the 1960s, after a series of riots in the United States sparked a popular belief that the causal factor was the summer heat. This belief was reinforced when the United States Riot Commission published a report showing that the majority of riots in 1967 began on days when the temperature was over $80^{\circ}$ F. Since then, a number of researchers have focused their efforts on studying the relationship between high ambient temperatures and aggressive behaviour. A few studies have also examined other weather conditions, including precipitation, sunlight, wind, and humidity, and points to the fact that as crime rate increases, the need for increase of police response to the crime challenges increases. But their studies were limited to advanced countries to the neglect of developing nations, and only to two variables, and not on multivariate studies. However [8] opined 'that crime rate are significantly depended on climate variability in the metropolis that is the wave of larceny, armed robbery, rape, murder and manslaughter increases with increase in rainfall and temperature. Also while larceny, robbery, rape correlated significantly with rainfall, murder correlated significantly with daily temperature. The high positive correlation of rainfall with larceny, armed robbery and rape is due to the fact that whenever it is raining the hoodlums set out for their operation and the sound of the rain fall always prevent the residents from hearing the footsteps of the criminals, and call for correlation study of climate and police operation in Nigeria.

It has been reported that when police suddenly leaves duty (that is the absence of police from checkpoints) there is likely to be an increase in crime [9]. Despite this the factors of criminal activity have received little of attention. And weather is one of such factors that affects criminal activity. However there is dearth of information on this because of little literature that has empirically investigated this relationship and mostly supports the conclusion that weather has a causal effect on criminal activity [8].

Delta State being an oil producing state, with huge commercial development in Asaba, Warri, Ughelli, Sapele, Agbor and Abraka, has lead to increased population and urbanization problems of housing, migration, robbery, Kidnapping etc in the state. This has increase the state monetary involvement in security operation. Because security is still often considered as primarily responsibility of state and federal government, this misses the truth that insecurity is a personal experience characterized by absence: absence of protection; of paths to redress grievance; of fair access to resources; and of rights. These insecurities are barriers to development and contribute to cycles of violence that prevent people leading safe, fulfilling and dignified lives. And climate variability has played a significant role in the process of development of these problems in the state. Succinctly, climatic variation has an effect in the monetary policy on security and police activities. However, the underlying problems of climatic variation in Delta State are flooding, storms, increased precipitation and high temperature, and according to [8] these have resulted in increase criminal activities in the state. This is manifested in form of severe weather (scorching sunshine and torrential downpour) that affects most police operations, and thus presents threat of injury to personnel, damaging equipment and structures, limiting ground and air mobility and air operations, and threatening troop morale. Electrical storms often accompany severe weather conditions and add the hazard of lightning strikes at munitions storage areas and fuelling points. Lightning also may interrupt landline 
communications and both communication and non-communication use of the electromagnetic spectrum.

Similarly, another climatic problem in Delta State is low visibility which is beneficial to offensive and retrograde operations and detrimental to defensive operations. In the offense, it conceals the concentration of maneuver or friendly forces, thus enhancing the possibility of achieving the element of surprise. Low visibility hinders the defense because cohesion and control become difficult to maintain, reconnaissance and surveillance are impeded, and target acquisition is less accurate. Smoke and obscurant aerosols can be expected on medium-intensity to high-intensity battlefields and may be used locally to reduce visibility. In all operations, obscurants limit the use of aircraft and aerial optical and infrared surveillance devices. Also effort levels of police officers may change depending on weather. Officers in the hot condition reported more aggressive and threatening impressions of the suspect, and were more likely to draw their weapon and shoot the simulated suspect. Concisely, climate effects on crime cannot be undermined. For instance, when it is raining, police may not decide to do a foot patrol. The temperament of police officers may also be affected by scorching weather. Increased temperatures may increase police aggression resulting in more arrests. Despite the problems studies in this area have been grossed over, thus there is a relative neglect of establishing the relationship between climate and policing. Based on this problem and neglect this study assesses the effects of climate change on police operation in Delta state.

\section{Methods of Data Collection}

The data used for this study were extracted from the archives of the Nigeria Meteorological Agency (NIMET), Nigeria Police headquarter, diary of the State head of Vigilante in Asaba from 1975-2014. The choice of these years is based on consistence, continuity, availability and wiliness to release of police operation and vigilante's data. Upon this same period of data was used for climate data. The climate data were collected from the archives of NIMET Warri, and MET Station of the Department of Geography and Regional Planning, Delta State University Abraka and were averaged and used for the study. Also field assistants who stayed close to area of checkpoints were used to obtain police and army checkpoints availability during rainy day and sunny day (see Figure 1), and also interview 18 officers (3 policemen at each major road where there are checkpoints) on

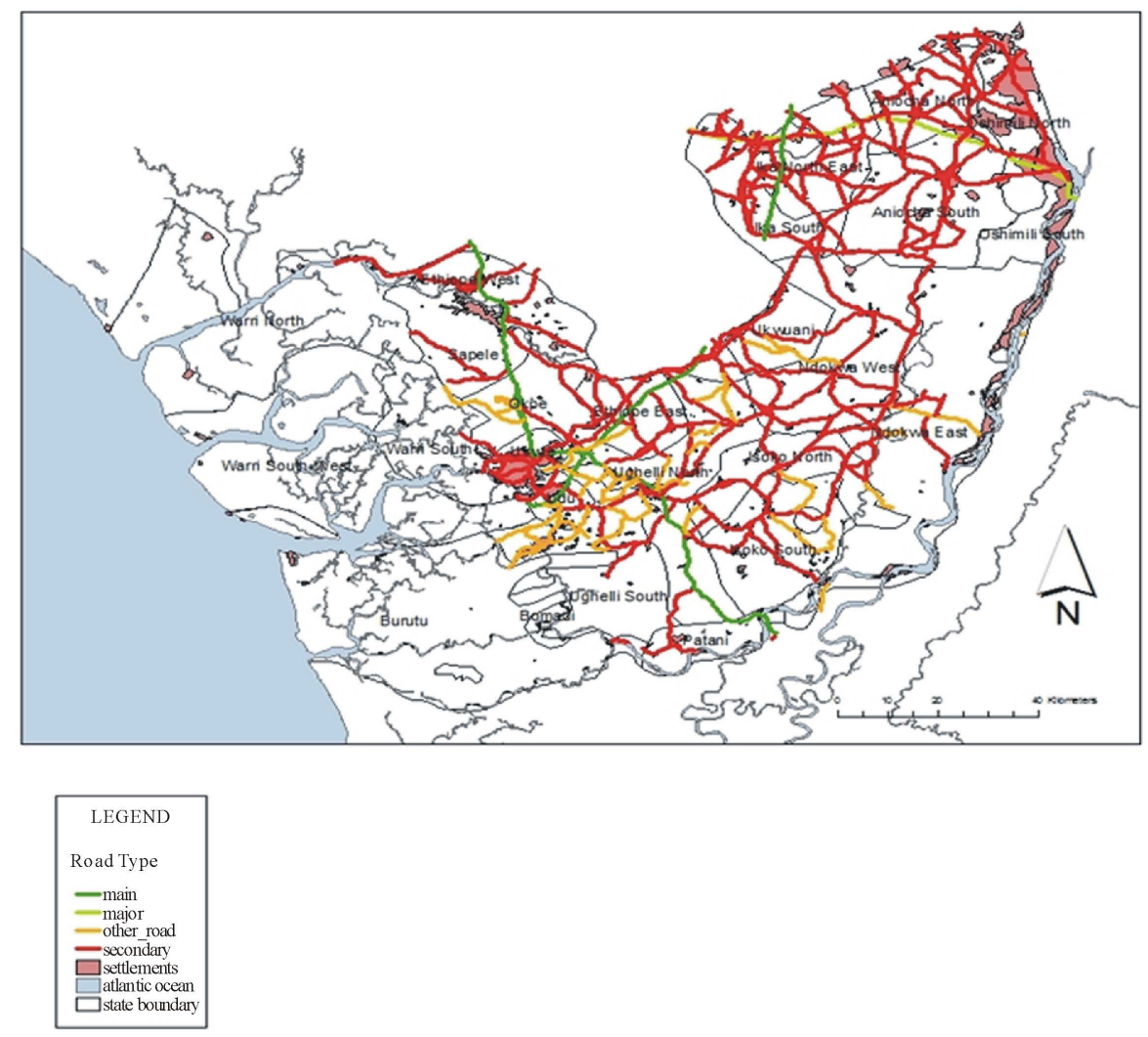

Figure 1. Distribution of roads in Delta state. 
checkpoints on the effects of rainfall and scorching weather on their activities. This corroborates [8]. Regression analysis was used to establish the effect of climate on police and vigilante operation in line with [10].

\section{Results and Discussion}

The data obtained for the study are presented in Tables 1-10 and Figures 2-4, and discussed below.

Figure 2 showed an annual mean of $3051 \mathrm{~mm}$ and $29.6^{\circ} \mathrm{C}$ for rainfall and temperature respectively, with three rainfall epochs 1975-1984 (2980 mm - $3100 \mathrm{~mm})$, 1985-1994 (3034 - $3090 \mathrm{~mm})$, and 1995-2014 (3007 - 3128 $\mathrm{mm}$ ). This showed an increase of $120 \mathrm{~mm} ; 56 \mathrm{~mm}$ and $121 \mathrm{~mm}$ in these epochs, and indicates that the first and last decades are wetter than the second epoch. This revealed an evidence of climate change in the state. Also Figure 2 showed $30^{\circ} \mathrm{C}$ mean annual temperature which span $28^{\circ} \mathrm{C}$ to $31^{\circ} \mathrm{C}$, indicating a rise of $3^{\circ} \mathrm{C}$ over the past 30 years in the state. Temperature also showed three epochs $1975-1984\left(28^{\circ} \mathrm{C}-29.6^{\circ} \mathrm{C}\right), 1985-1994\left(29.5^{\circ} \mathrm{C}-\right.$ $\left.30.9^{\circ} \mathrm{C}\right)$ and $1995-2014\left(30^{\circ} \mathrm{C}-31^{\circ} \mathrm{C}\right)$, with a warming of $1.6^{\circ} \mathrm{C}, 1.4^{\circ} \mathrm{C}$ and $1^{\circ} \mathrm{C}$, and showed a decadal change in temperature. This is also an evidence of climate change. Rainfall and temperature revealed 0.69 and 0.64 corre-lation value, both indicate an upward trend from 1975-2014. This however corroborated [11] [12]. The increase in rainfall from 1995-2014 coincide with those of police and vigilante deployment to street/roads in the state (see Figure 3).

The mean annual deployment of police and vigilante to various street/roads in Delta state showed a general increase from 1975 to 2014 with annual mean of 712, 51 and 447 respectively for street/road patrol, police investigation and vigilante deployment (see Figure 3). Figure 3 showed clearly an upward trend in the number of street patrol by police, police criminal investigation and vigilante patrol in the street, with $0.97,0.67$ and 0.66 correlation values with the years respectively. This indicates that as the year's increases there is upward increase

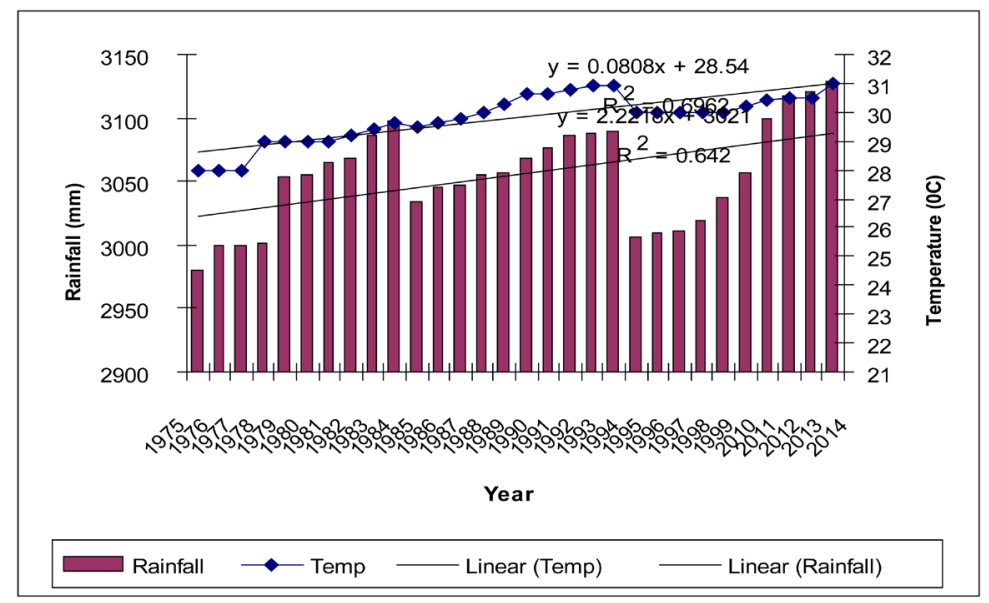

Figure 2. Distribution of rainfall $(\mathrm{mm})$ and temperature $\left({ }^{\circ} \mathrm{C}\right)$.

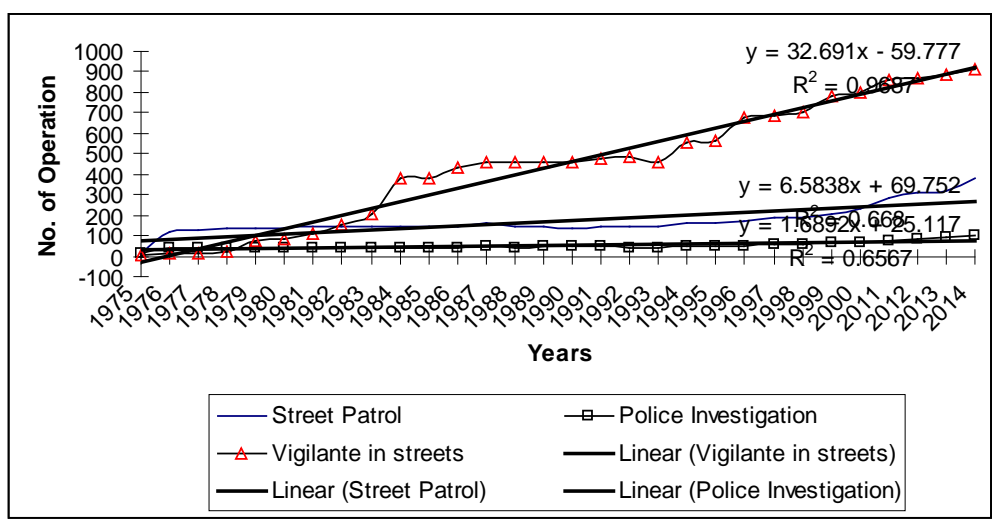

Figure 3. Mean distribution of police and vigilante deployed. 


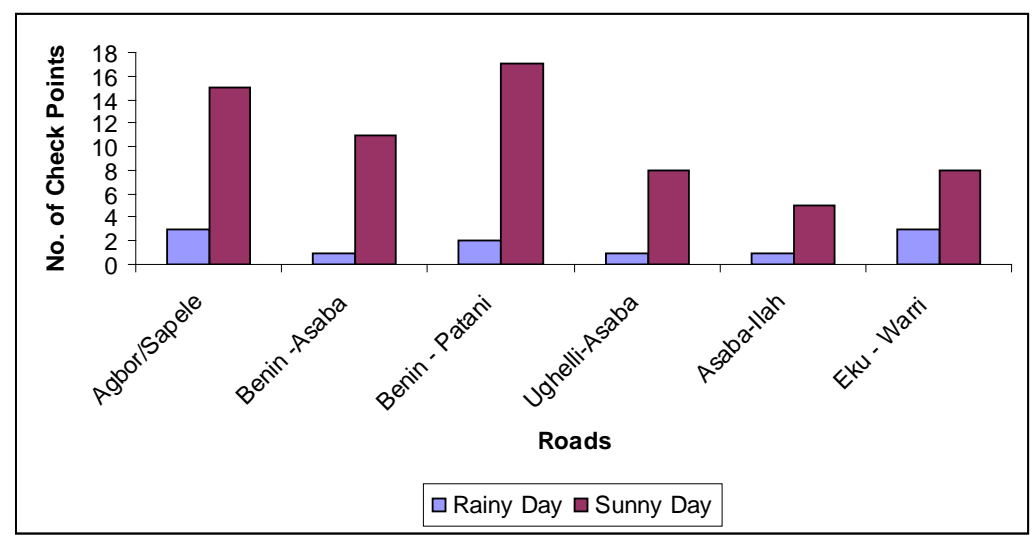

Figure 4. Mean number of checkpoints.

in police operation in the state. The increased according to the police officers interviewed is as a result of population increase over the years which precipitate increase in criminality in the state, as well as variation in rainfall and temperature over the years [8]. Their result revealed that crime rate in Warri metropolis, are significantly depended on climate variability, and that the wave of larceny, armed robbery, rape, murder and manslaughter increases with increase in rainfall and temperature. Also there frequent reported cases of armed robbery, murder and kidnapping along Agbor Sapele roads, Abgor-Asaba, Ughelli-Asaba and along DSC express way when it is raining, during festive periods (Christmas, new year celebration), and electioneering period were some politicians commit heinous crimes to secure elective post, as such more police officers are deployed to these roads [8].

The monthly rainfall, temperature and police and vigilante operation are shown in Table 1. It showed clearly that the months with the highest rainfall values of $411 \mathrm{~mm}$ and $421 \mathrm{~mm}$ (July and September) coincides with the months with the lowest police highway patrol, street patrol, police investigation and vigilante operation. This showed that as rainfall increases, there reduction in the number of street and high patrol, and criminal investigation by police officers in the state. This confirmed the earlier view of [8]. They opined that the high positive correlation of rainfall with larceny, armed robbery and rape is due to the fact that whenever it is raining, the hoodlums set out for their operation and the sound of the rain fall always prevent the residents from hearing the footsteps of the criminals. Also the Vigilante are trapped by the rain and flood pondages, as such there is no proper surveillance, as such there is reduced deployment of police and vigilante.

Generally high numbers of policemen were deployed for checkpoints under sunny days than a rainy day. Table 2 and Figure 4 indicate a total of 64 checkpoints with police officers compared to only 11 checkpoints when it is raining. Other details are listed on Table 3. The functional checkpoints on these roads are the one mounted by the Nigeria Army, who maintains continuous watched, stop and checks on the road be it raining or sunny. For instance there are 3 permanent army checkpoints on Eku-Warri road and Benin-Patani express roads where army maintain regular stop and checks on the road be it raining or sunny. Also interaction with the officers and commuters revealed that when it is raining heavy most of the officers retire to the station or base, to return after the rain, and same is said of hot afternoon.

Table 3 showed $0.90,0.79$ and 0.65 correlation values between temperature, rainfall and police street patrol, highway patrol and police investigation respectively, this indicate that temperature and rainfall has $80 \%, 63 \%$, and $43 \%$ contribution to police street patrol, highway patrol and police investigation respectively in the state. However, motivation, vehicles availability, gun/bullet availability, funding etc are responsible for the other percentage of the factors that affect police prompt response to crime in the state. Thus indicating that as rainfall and temperature increases there responding increase in the police operation in the state. Tables 4-6 showed the standardized coefficient and $t$ values for highway patrol, street patrol and police investigation. The $t$ values of $-1.291,-1.012$ and -1.433 for highway patrol, street patrol and police investigation respectively showed that police operation are significant at $\mathrm{p}<0.05$. Thus police operations in the state are significantly dependent on temperature and rainfall. The negative values indicate that as rainfall and temperature increases, there is reduction in police activities on the various roads and street in Delta state. It is therefore required that police incorporate weather as a decision variable when deciding on the level and intensity of policing [7] [13]. First, police de- 
Table 1. Mean monthly climate, police and vigilante operation.

\begin{tabular}{|c|c|c|c|c|c|c|}
\hline Months & Rainfall (mm) & Temp $\left({ }^{\circ} \mathrm{C}\right)$ & Vigilante on street & Highway patrol operation & Street patrol & Police investigation \\
\hline January & 21 & 29.2 & 864 & 62 & 221 & 49 \\
\hline February & 86 & 30.6 & 550 & 71 & 263 & 52 \\
\hline March & 67 & 30 & 459 & 65 & 266 & 55 \\
\hline April & 138 & 30.9 & 778 & 55 & 250 & 56 \\
\hline May & 209 & 30.5 & 655 & 42 & 140 & 56 \\
\hline June & 383 & 29.2 & 578 & 42 & 120 & 60 \\
\hline July & 411 & 29 & 360 & 33 & 109 & 45 \\
\hline August & 47 & 29.7 & 740 & 39 & 131 & 60 \\
\hline September & 421 & 28.6 & 340 & 32 & 82 & 46 \\
\hline October & 369 & 31.6 & 772 & 58 & 147 & 66 \\
\hline November & 67 & 30.8 & 880 & 61 & 322 & 75 \\
\hline December & 18 & 30.5 & 903 & 78 & 369 & 76 \\
\hline
\end{tabular}

Table 2. No. of check points during rainy day and sunny day.

\begin{tabular}{ccc}
\hline Roads & Rainy Day & Sunny Day \\
\hline Agbor/Sapele & 3 & 15 \\
Benin-Asaba & 1 & 11 \\
Benin-Patani & 3 & 17 \\
Ughelli-Asaba & 1 & 8 \\
Asaba-Ilah & 1 & 5 \\
Eku-Warri & 3 & 8 \\
Total & 11 & 64 \\
\hline
\end{tabular}

Table 3. Temperature, rainfall correlation with police street patrol, highway patrol and police investigation.

\begin{tabular}{ccccc}
\hline Model & $\mathrm{R}$ & $\mathrm{R}$ Square & Adjusted R Square & Std. Error of the Estimate \\
\hline Street Patrol & $0.895(\mathrm{a})$ & 0.802 & 0.758 & 45.61233 \\
Highway Patrol & 0.793 & 0.628 & 0.545 & 10.25607 \\
Police Investigation & 0.652 & 0.425 & 0.297 & 8.50612 \\
\hline
\end{tabular}

(a) Predictors: (Constant), Temp, Rainfall.

Table 4. Temperature, rainfall and highway patrol standardized coefficients (a).

\begin{tabular}{ccccccc}
\hline \multirow{2}{*}{ Model } & & \multicolumn{2}{c}{ Unstandardized Coefficients } & Standardized Coefficients & T & Sig. \\
\cline { 3 - 7 } & & B & Std. Error & Beta & B & Std. Error \\
\hline \multirow{2}{*}{1} & (Constant) & -140.019 & 108.476 & & -1.291 & 0.229 \\
& Rainfall & -0.053 & 0.020 & -0.565 & -2.640 & 0.027 \\
& Temp & 6.755 & 3.568 & 0.405 & 1.893 & 0.091 \\
\hline
\end{tabular}

(a) Dependent Variable: Highway Patrol.

Table 5. Temperature, rainfall and police street patrol coefficients (a).

\begin{tabular}{|c|c|c|c|c|c|c|}
\hline \multirow{2}{*}{ Model } & & \multicolumn{2}{|c|}{ Unstandardized Coefficients } & \multirow{2}{*}{$\begin{array}{c}\text { Standardized Coefficients } \\
\text { Beta }\end{array}$} & \multirow{2}{*}{$\begin{array}{l}\mathrm{T} \\
\mathrm{B}\end{array}$} & \multirow{2}{*}{$\begin{array}{c}\text { Sig. } \\
\text { Std. Error }\end{array}$} \\
\hline & & $\mathrm{B}$ & Std. Error & & & \\
\hline \multirow{3}{*}{1} & (Constant) & -627.879 & 620.411 & & -1.012 & 0.338 \\
\hline & Rainfall & -0.384 & 0.114 & -0.677 & -3.370 & 0.008 \\
\hline & Temp & 29.987 & 20.405 & 0.295 & 1.470 & 0.176 \\
\hline
\end{tabular}

(a) Dependent Variable: Street Patrol. 
Table 6. Temperature, rainfall and police investigation coefficients (a).

\begin{tabular}{ccccccc}
\hline \multirow{2}{*}{ Model } & & \multicolumn{2}{c}{ Unstandardized Coefficients } & Standardized Coefficients & T & Sig. \\
\cline { 3 - 7 } & & B & Std. Error & Beta & B & Std. Error \\
\hline \multirow{3}{*}{1} & (Constant) & -128.902 & 89.967 & & -1.433 & 0.186 \\
& Rainfall & -0.012 & 0.017 & -0.190 & -0.714 & 0.493 \\
& Temp & 6.293 & 2.959 & 0.566 & 2.127 & 0.062 \\
\hline
\end{tabular}

(a) Dependent Variable: Police investigation.

Table 7. Relationship between temperature, rainfall and vigilante.

\begin{tabular}{ccccc}
\hline Model & $\mathrm{R}$ & R Square & Adjusted R Square & Std. Error of the Estimate \\
\hline 1 & $0.736(\mathrm{a})$ & 0.542 & 0.441 & 148.48042 \\
\hline
\end{tabular}

(a) Predictors: (Constant), Temp, Rainfall.

\section{Table 8. Correlations.}

\begin{tabular}{lcccc}
\hline & Variables & Vigilante & Rainfall & Temp \\
\hline \multirow{2}{*}{ Pearson Correlation } & Vigilante & 1.000 & 0.768 & -0.692 \\
& Rainfall & -0.768 & 1.000 & -0.842 \\
& Temp & -0.692 & -0.842 & 1.000 \\
\hline
\end{tabular}

Table 9. Standardized coefficients (a).

\begin{tabular}{|c|c|c|c|c|c|c|}
\hline \multirow[t]{2}{*}{ Model } & & \multicolumn{2}{|c|}{ Unstandardized Coefficients } & \multirow{2}{*}{$\begin{array}{c}\text { Standardized Coefficients } \\
\text { Beta }\end{array}$} & \multirow{2}{*}{$\begin{array}{l}\mathrm{T} \\
\mathrm{B}\end{array}$} & \multirow{2}{*}{$\begin{array}{c}\text { Sig. } \\
\text { Std. Error }\end{array}$} \\
\hline & & B & Std. Error & & & \\
\hline \multirow[t]{3}{*}{1} & (Constant) & 3388.743 & 1697.693 & & 1.996 & 0.077 \\
\hline & Rainfall & -0.647 & 0.625 & -0.557 & -1.035 & 0.327 \\
\hline & Temp & -76.661 & 47.908 & -0.861 & -1.600 & 0.144 \\
\hline
\end{tabular}

(a) Dependent Variable: Vigilante.

Table 10. Perceived factors affecting police and vigilante operation.

\begin{tabular}{ccc}
\hline Climate factors & Yes & No \\
\hline Heavy rainfall & $18(100 \%)$ & $1(6 \%)$ \\
High sunshine & $17(94 \%)$ & $3(17 \%)$ \\
Scorching temp $12-2 \mathrm{pm}$ & $18(100 \%)$ & $5(28 \%)$ \\
Flooding & $15(83 \%)$ & $13(72 \%)$ \\
Gullies & $15(83 \%)$ & $3(17 \%)$ \\
\hline
\end{tabular}

partments may have already observed the relationship between weather and crime and adjusted police presence accordingly. If the police presence is consistently higher in finer weather, we would expect this to result in fewer crimes occurring as criminals acknowledge the increased probability of being caught, but this is not so in Delta State Second, effort levels of police officers may change depending on weather. Officers in the hot condition reported more aggressive and threatening impressions of the suspect, and were more likely to draw their weapon and shoot the simulated suspect. Succinctly, climate variability and crime cannot be undermined. For example, if it is raining, police may not decide to do a foot patrol. The temperament of police officers may also be affected by weather. Increased temperatures may increase police aggression resulting in more arrests [14]. 
Table 7 showed 0.74 correlation value between temperature, rainfall and vigilante operation, this indicate that temperature and rainfall has 54\% contribution to vigilante operation in the state. However, rainfall has inverse relationship $(-0.77)$ and temperature $(-0.69)$ (see Table 5), indicating that as rainfall and temperature increases, there reduction in the operation of vigilante operation. The $t$ value of 1.996 is however significant at $p>0.05$ (see Table 9. Thus vigilante operation in the state is significantly dependent on temperature and rainfall. Based on this the three tier of government should invest more on community policing (vigilante) by motivating then with modern incentives so as to encourage them to work assiduously during when hazards. This is because Ccommunity Security is a powerful approach that builds human security and contributes to wider peace and development goals. If the peace and development community are to make good on our commitments to strengthen relations between states and societies and improve people's experiences of security, Community policing should become a principal tool shaping the policies and programmes of international actors.

Table 10 revealed the perceived factors. It revealed that $72 \%$ and above respondents are of the view that climate factors of gullies, flooding, high dew, high sunshine, scorching temperature in the hours of 12 - 2 pm and heavy rainfall are responsible reduce number of checkpoints and street patrol in Delta state, however temperature and rainfall had 100\% influence. This corroborated the earlier view in Table 1 and those of [8].

\section{Conclusion}

The study showed an evidence of climate change in delta state with a rise of $3^{\circ} \mathrm{C}$ in temperature, and decadal rainfall increase of $120 \mathrm{~mm} ; 56 \mathrm{~mm}$ and $121 \mathrm{~mm}$ in three epochs (1975-1984, 1985-1994 and 1995-2014). However, the first and last decades are wetter than the second epoch. Police and vigilant operations experience a gradual increase from 1975 to 2014, and their operations are significantly dependent on increase in rainfall and rise in temperature. It's therefore recommended that the federal and state government should provide rain coat, safety boot, umbrella, good vehicles to police and vigilantes on duty; and police officers and vigilantes should embark on regular patrol be it raining or sunny day. This will aid their effective operation when it is raining and during scorching period.

\section{References}

[1] Satterthwaite, D., Huq, S., Pelling, M., Reid, A. and Romero-Lankao, P. (2007) Building Climate Change Resilience in Urban Areas and among Urban Populations in Low- and Middle-Income Countries, Commissioned by the Rockefeller Foundation. International Institute for Environment and Development (IIED) Research Report, ll2.

[2] Sherman, L.W., Gartin, P.R. and Buerger, M.E. (1989) Hot Spots of Predatory Crime: Routine Activities and the Criminology of Place. Criminology, 27, 27-55. http://dx.doi.org/10.1111/j.1745-9125.1989.tb00862.x

[3] Garzino, S.J. (1982) Lunar Effects on Mental Behavior: A Defense of the Empirical Research. Environment and Behaviour, 14, 395-417. http://dx.doi.org/10.1177/0013916582144001

[4] Bolander, A.M. (1972) Nordic Suicide Statistics. In: Waldenstrom, J., Larsson, T. and Liungstedt, N., Eds., Suicide and Attempted Suicide, Nordiska Bokhandelns Forlog, Stockholm, 57-58.

[5] Barraclouoh, B.M. and White, S.J. (1978) Monthly Variation of Suicidal, Accidental and Undetermined Poisoning Deaths. British Journal of Psychiatry, 132, 279-282.

[6] Cohn, E.G. (1988) A Review of the Effect of Climatic and Temporal Variations on Crime. M. Phil Thesis, University of Cambridge, Cambridge.

[7] Cohn, E.G. (1990) Weather and Crime. British Journal of Criminology, 30, 51-64.

[8] Efe, S.I. and Ndakara, E.O. (2010) Impact of Climate Variability on Crimes in Warri Delta State, Nigeria. In: Akpotor, A.S., Ohwona, A.I. and Igun, U.A., Eds., Reading in Homeland Security and Development, A Publication of the Faculty of the Social Sciences, Delsu Abraka, Nigeria, 17-24.

[9] Sherman, L.W. and Eck, J.E. (2002) Policing for Prevention. In: Sherman, L.W., Farrington, D. and Welsh, B., Eds., Evidence Based Crime Prevention, Routledge, New York.

[10] Efe, S.I. and Weli, V. (2015) Economic Impact of Climate Change in Port Harcourt. Nigeria Open Journal of Social Sciences, 3, 57-68. http://www.scirp.org/journal/jss

[11] Efe, S.I. (2006) Regionalisation of Nigerian Climate: A Recent Approach. The Nigerian Academic Forum, 11, 32-39.

[12] Efe, S.I. (2007) Climate of Delta State. In: Odemerho, F.O., et al., Eds., Delta in Maps, Occasional Publication of the Department of Geography and Regional Planning, Delsu, Abraka, 24-30. 
[13] Cohn, E.G. and Rotton, J. (2000) Weather, Seasonal Trends and Property Crimes in Minneapolis, 1987-1988. A Moderator-Variable Time-Series Analysis of Routine Activities. Journal of Environmental Psychology, 20, 257-272. http://dx.doi.org/10.1006/jevp.1999.0157

[14] Vrij, A., van der Steen, J. and Koppelaar, L. (1994) Aggression of Police Officers as a Function of Temperature: An Experiment with the Fire Arms Training System. Journal of Community and Applied Social Psychology, 4, 365-370. http://dx.doi.org/10.1002/casp.2450040505 